\title{
The Legal Background
}

Litigation describes the process of taking disputes to court. With the help of Article 263 TFEU (Treaty on the Functioning of the European Union) annulment litigation, different kinds of actors can take to the Court of Justice of the European Union (CJEU) disputes with European Union (EU) institutions over the legality of these institutions' actions. The Court will review the legality of these actions and decide whether to declare them void.

Annulment actions thus constitute an important part of the EU's system of judicial protection (Arnull 2011), which also comprises the infringement procedure and the preliminary reference procedure. The infringement procedure, set out in Article 258 TFEU, allows the Commission to address and challenge member states' violations of EU law. In this context, the Commission enjoys the privilege of transferring cases to the EU's judicial arena whenever member states fail to modify their application of EU law in response to reasoned opinions in which the Commission explains why it believes the respective member state to be in violation of its treaty obligations and demands further information and appropriate adjustments from the member state (Tallberg 2002; Börzel 2003; Hartlapp 2005, chapter 6). Even though most infringement proceedings do not reach this judicial phase, infringement cases eventually brought before the Court still represent a substantial part of its overall workload (Arnull 2006, 35; Falkner 2018). In contrast, the activation of the CJEU in the context of Article 267 TFEU preliminary

(C) The Author(s) 2020

C. Adam et al., Taking the EU to Court, Palgrave Studies in European Union Politics, https://doi.org/10.1007/978-3-030-21629-0_3 
reference procedures is the privilege of national courts. Under this procedure, national courts can refer to the CJEU questions regarding the interpretation of the treaty and the validity and interpretation of acts of the institutions, bodies, offices, or agencies of the EU. Preliminary rulings have played a significant role in the development of Community law, as it is through these exchanges between national courts and the CJEU that crucial concepts, such as, for example, the direct effect and the supremacy of EU law, have been developed (Craig and de Burca 2011, 461). As such, preliminary reference proceedings have been an important channel through which the constitutionalization of the European treaties has emerged. This channel has been turned from being an instrument to assure equal application of EU law before domestic courts into being an instrument to challenge national laws and even national constitutional law in breach of EU law in national courts (Alter 1998).

Yet while research on the role of infringement procedures on the Europeanization of national policies, as well as research on the role of preliminary rulings on the trajectory of European integration, abound in political science research, actions for annulment have attracted much less attention from this group of scholars. This is rather striking. After all, the action for annulment is the only legal instrument with which member states, EU institutions, and even citizens, companies, interest groups, and regional governments can directly activate the CJEU and ask for judicial review. Annulment actions thus constitute a direct road to Luxembourg without having to take a detour through national courts, although-as will be discussed below-this direct route is not open to all applicants under all circumstances at all times.

While we are mainly interested in the political role of annulment litigation, this is hardly possible without appreciating the legal background. To understand why disputes are taken to court, we need to understand the legal context specifying when actors will actually be able to go to court successfully. The use of any legal instruments will be influenced by rules regulating their use. This is the essence of the message conveyed by the literature on legal opportunity structures. Depending on the options a legal system provides, for example the rights attributed to certain kinds of actors to file suits in particular constellations, actors' decisions to take recourse to litigation are conditioned, with respective effects (Andersen 2006; Conant 2006; Hilson 2002; Wilson and Rodriguez Cordero 2006; Vanhala 2012). Social movements' litigation strategies provide good examples. The more open the legal system is for bringing 
policy-related decisions into the legal arena, the more options social movements enjoy to employ litigation in the struggle for their cause. However, legal access is nothing "static" or a priori given nor refused forever. Quite the opposite. The judges tend to develop the underlying law in their judgements; their judgements on individual cases thus bring novel interpretations that, in turn, often influence constitutional or treaty-base revisions. Therefore, rules regulating the access to courts in certain matters may change over time-thus altering the dynamic of the policy processes due to a redistribution of access rights to litigate (Wilson and Rodriguez Cordero 2006). As we want to understand policy stakeholders' decisions to litigate with the help of annulment actions, the legal framework regulating these actors' capacity to launch annulment cases are of great interest. Before this background, this chapter revisits the EU legal framework that specifies the use of annulment actions.

This endeavour is actually quite challenging. After all, political scientists are inclined to quickly skim such legal elaborations or to skip them completely when these elaborations seem detailed and technical. This is a pity, however, since knowing this legal background is important for understanding the political role of any kind of legal instrument. At the same time, no matter how detailed and technical those writers with a background in political science think their writings are, it will be tough for them to meet the high standards of legal scholarship. We try to find a compromise that is as accessible as possible to political scientists without being perceived by legal scholars of annulment actions to be overly simplistic and superficial. This means that the following cannot be a complete history of relevant case law and judicial interpretations on annulment actions. Instead, we try to eclectically describe the most important legal developments that seem relevant to understanding the political role of annulment litigation in the EU.

\section{Actions for Annulment: Some Essentials}

Annulment actions have been a part of the treaties ever since the Treaties of Rome. Since the Treaty of Lisbon, we find the legal provisions guiding the application of actions for annulment in Article 263 TFEU. ${ }^{1}$ This article essentially defines three key aspects that determine the possibility of initiating a successful action for annulment: the range of legal acts that can be challenged, the grounds on which legal acts will be annulled, and the types of actors that may initiate annulment proceedings. More 
specifically, Article 263 comprises six paragraphs. In the first paragraph, the treaty lists the type of acts that can be reviewed by the Court. The second paragraph deals with privileged applicants and the grounds that may justify starting an annulment. The third paragraph is about semi-privileged applicants, and the fourth is about non-privileged applicants. A new fifth paragraph specifies conditions related to non-privileged applicants, and the last paragraph presents the time limit for initiating annulment actions.

Until 1989, the European Court of Justice was solely responsible for decisions on annulment actions. This changed with the creation of the Court of First Instance, which relieved the Court from many of these cases. This was the case at least at the first instance of these cases, whereas the European Court of Justice remained responsible for appeals against annulment judgements by the Court of First Instance. Initially, the Court of First Instance was competent on annulment actions brought by private applicants (mainly regarding competition policy). In 1993 and 1994, it became competent to examine all annulment action cases initiated by private parties (Bellamy 2010, 35-36). In 2004, the Court of First Instance's competences have been further extended. Among other things, it is charged with deciding actions initiated by the member states that are directed against the Commission and against the Council in certain cases in the fields of state aid and (external) trade protection. Moreover, it should hear actions for annulment brought against the Council that resulted from the exercise of its implementing powers, and it was charged with deciding actions directed against the European Central Bank (ECB) (Fairhurst 2010, 182). The Treaty of Lisbon further rearranged the distribution of competences between the two Courts. Not only does it rename the Court of First Instance the General Court, it also charged this General Court with hearing all actions for annulment, except those that involved only EU institutions (e.g. horizontal cases), and actions brought by the member states against the European Parliament (EP) or the Council as long as these had not already been transferred to the Court of First Instance in 2004.

When deciding annulment cases, both Courts have and will assess whether actions are founded based on four legal grounds specified in Article 263(2) that applicants may invoke: lack of competence, infringement of an essential procedural requirement, infringement of the treaties or of any rule of law relating to their application, or misuse of powers. 
There are two main types of lack of competence. The first constitutes a breach of the principle of conferral entailed in Article 5(2) Treaty on European Union, which stipulates that the EU may act only in those areas in which it has been conferred powers through the treaties. However, the Court has generally relied on a generous interpretation of the powers conferred to the EU (Hartley 2007, 398). For example, it has developed the doctrine of implied powers (ERTA C-22/70) and has only rarely recognized a breach of the principle of conferral (Horspool and Humphreys 2012, 255). The second type of lack of competence occurs where an EU institution breaches the principle of institutional balance by overstepping the powers of another EU institution. Frequent conflicts between the Council and the EP arose in this context about the appropriate legal basis for legislative action. Since the influence of the EP in the decision-making process depends on the legal basis on which an act or a policy is adopted, the Court was often called to assess whether an act of the Council was adopted under the correct legal basis. This type of situation has also been addressed through the second ground for annulment: the infringement of essential procedural requirements.

A classic example of violation of procedural requirement is the failure to consult an EU body when the procedural rules applying to the decision required the consultation of that body. In Roquette (C-138/79), for example, the Court annulled a measure adopted by the Council under the consultation procedure because the Council had adopted the act without the opinion of the EP. Moreover, the obligation to provide an adequate statement of reasons, in particular a statement of the legal basis upon which the measure is adopted, constitutes another important procedural requirement for annulment actions. Finally, the breach of the rights of defence (e.g. the right to be heard, or access to documents for stakeholders during the preparation of the act) is also frequently used to justify an annulment action.

The third ground to invoke annulments is the infringement of the treaty or any rule relating to its application. This is the widest ground for actions in annulment. It covers not only all constitutive treaties and Community legal acts but also some of the EU's international agreements, as well as unwritten general principles of law that have been developed by the Courts themselves (Türk 2009, 127-128), such as the principles of legal certainty and legitimate expectations. These principles are particularly relevant when the Community adopts rules that concern events that lie in the past. Retroactive rules are allowed only when the 
public interest weights more than the private interest in the maintenance of the status quo. The other three important principles are the principles of equality, proportionality, and fundamental rights.

Finally, the actions of EU institutions will be annulled when these institutions have misused their powers in taking that action. More specifically, a misuse of powers seems to have occurred when disputed measures 'appear[s], on the basis of objective, relevant and consistent evidence, to have been taken with the exclusive or main purpose of achieving an end other than that stated or evading a procedure specifically prescribed by the Treaty' (T-415/03). Annulment actions based on misuse of powers are, however, rarely successful because of the difficulty for applicants to provide objective evidences of the motives of the author of the act (Türk 2009, 142-145) and thus attract fewer litigation decisions.

From a legal perspective, a thorough explanation of the grounds on which one initiates an action for annulment is obviously essential. From a political science perspective, however, it is interesting to see that in practice, the majority of annulments that we coded were not initiated with reference to any single one of those grounds. Instead, applicants typically try to make the case for several of these grounds at the same time.

It is important to highlight that successful actions for annulment must not only be founded, they also must be initiated within the appropriate time limits stipulated in Article 230(5). Specifically, proceedings 'shall be instituted within two months of the publication of the measure, or of its notification to the plaintiff, or, in the absence thereof, of the day on which it came to the knowledge of the latter, as the case may be'. This can be quite a demanding deadline for potential applicants. After all, in case no action for annulment reaches the Court before this deadline, it considers that all potential applicants have implicitly accepted the legality of the EU legal act. For example, in the event that member states fail to challenge an unwelcome decision by the Commission on domestic state aid arrangements with an action for annulment, they miss the chance to have the Court review the legality of the decision later on. Consequently, if member states simply ignore such a decision by the Commission, the Commission can involve the Court under the infringement procedures without running the risk of having the Court review the legality of that decision in the process of these proceedings. Consequently, actions for annulment are imminent manifestations of conflict that indicate conflict without substantial delay. Moreover, they are not simple substitutes for infringement proceedings but fulfil their own distinct legal role. 
In case actions for annulment are founded-based on any of the legal grounds discussed above-and have been initiated in time, the Court shall, according to Article 231(1), declare the respective EU legal act void. That means the Court deprives this legal act of its legal effect. In fact, the annulment of the act applies retroactively and has effect erga omnes in that annulments apply generally and are not limited to the applicant.

But before the Court will even assess whether an action for annulment is founded, it will first evaluate whether the case is admissible at all. Two aspects that have raised considerable controversy in this regard are the types of legal acts that can be subjected to annulment review and the types of actors that can make use of annulment actions. In fact, the wording of Article 263 TFEU has been modified several times since its original conception with respect to these two questions. Most of these treaty changes have been motivated by the intent to accommodate the Court's interpretation of both aspects within its respective case law at the time. While legal scholars continue to criticize the restrictive rules that make it difficult-particularly for private actors to access the Court through annulment actions-this evolution has overall led to a considerable extension of the list of reviewable acts and of eligible applicants.

\section{An Evolving Set of Reviewable Acts}

Article 263(1) lists the type of acts that can be reviewed by the Court of Justice under the annulment regime. These are legislative acts, acts of the Council, acts of the Commission, and acts of the ECB, other than recommendations and opinions. Acts of the EP and of the European Council, as well as acts of bodies, offices, or agencies of the EU can also be reviewed-as long as these acts are intended to produce legal effects vis-à-vis third parties.

Primary law thus explicitly states that annulment actions can be initiated against EU legislative acts. These legislative acts are defined within Article 289 TFEU as those legal acts adopted under the ordinary legislative procedure or under the special legislative procedure. The ordinary legislative procedure corresponds to the former co-decision procedure, which grants equal weight to the EP and the Council in the decision-making process. Special legislative procedures replace the former consultative, cooperation, and assent procedures. In those procedures, the Council of the EU is the main legislator, while the EP is less 
influential as its role is restricted to consultation or approval. Moreover, in Article 263(1), primary law also explicitly holds that annulment actions can be directed against acts of the Council, the Commission, and the $\mathrm{ECB}$, other than recommendations and opinions.

While these provisions seem rather clear on a first glance, they have been the subjects of quite a few legal controversies. Very prominently, the Commission and the Council found themselves in disagreement over whether atypical actions, other than clearly reviewable regulations, directives, and decisions other than the explicitly non-reviewable recommendations and opinion, should also be reviewable through annulment actions. In ERTA (C-22/70), the Court declared for the first time that instead of focusing on the form of a challenged act, it would first consider its substance when reviewing the applicability of an action for annulment. The specific conflict erupted over the renegotiation of the European Agreement concerning work of crews of vehicles in international road transport in the context of the United Nation's Economic Commission for Europe. This agreement specified regulatory aspects such as standardized rest periods for drivers. In preparation of these negotiations at the international level, EU member state governments had discussed their negotiation strategy within a Council meeting and had synthesized the results of these discussions within written proceedings. The Commission demanded that the Court declare these proceedings void since it saw itself competent and responsible for negotiating this treaty at the international level. While the Court in this case has left a substantial mark on the organization of the EU's external relations, ${ }^{2}$ it also influenced the annulment procedure itself by stating that according to its interpretation of the treaties, annulment actions could be initiated against 'all measures adopted by the institutions, whatever their nature or form' as long as they were 'intended to have legal effects' (C-22/70). With this interpretation, the Court substantially extended the range of acts subject to annulment actions to also involve atypical acts, such as, for example, conclusions adopted by the Council, letters written by the staff of the Commission, or oral decisions (Türk 2009, 12).

While the question of what constituted such legal effects remained, however, the Court clarified in IBM, more than ten years after ERTA, that it considered acts to be exerting legal effect when they are 'binding on, and capable of affecting the interests of, the applicant by bringing about a distinct change in his legal position' (C-60/81). With 
this interpretation, the Court has also made clear that simply disguising legal acts as non-binding acts by label would be insufficient to make them immune to review through annulment litigation. In case C-57/95, the Court, for example, annulled a communication issued by the Commission because it saw this communication as having clear legal effects for the member states.

Moreover, in Les Verts p. European Parliament (C-294/83), the Court further extended the range of reviewable acts by including those acts adopted by the EP that have legal effects vis-à-vis third parties. Since the original treaty provision had not listed the EP as a potential defendant in annulment litigation (Arnull 2000, 182-183), legal acts by the EP were not considered to be the subject of annulment litigation. Yet with the extended competences of the EP, this provision came to be questioned more and more strongly. In this specific case, the French ecological nonprofit Les Verts, a predecessor of the French party Les Verts, Confédération Écologiste-Parti Écologiste, which subsequently became the party Europe Écologiste-Les Verts, had initiated a series of actions for annulment against various EU institutions over the allocation of EU funds to reimburse political information campaigns in the context of the European elections in 1984. Specifically, they claimed that by the manner in which (in this case) the bureau of the EP had allocated these funds, the Parliament had unduly used its power to favour those parties that had already been elected to the EP before the 1984 election. With this application for an annulment of how these funds were allocated, the Court had to consider whether it would even be competent to review the legality of actions by the EP. Interestingly, at the oral stage in the proceedings, the EP held that its legal acts could not be subjected to annulment litigation at least as long as the Parliament itself did not have the right to challenge other institutions' legal acts via annulment litigation. This was an interesting suggestion that could have helped the Parliament to either reject the legal challenge in this case or at least gain the right to bring annulment cases against other EU institutions itself. As the advocate general and the Court did not follow this reasoning, this became known only for adding the EP to the list of potential defendants in annulment litigation. With the Maastricht Treaty, the member states followed up on this by formally extending the list of reviewable acts of Article 263 to include acts of the EP, acts adopted jointly by the EP and the Council, and acts adopted by the ECB. 
Particularly the last episode in this brief overview over the evolution of actions reviewable through actions for annulment highlights the fact that actions for annulment emerge where EU institutions are competent to adopt binding legal acts or where these institutions presume to have this right. Consequently, the historical pattern of annulment litigation is reflective of the (successful) strive for increasing competences by EU institutions. As long as EU institutions are unable to adopt typical legally binding acts and as long as they do not try to impose legal effects in other ways, actions for annulment are irrelevant. Yet, as the example of the EP has indicated, as soon as EU institutions start to gain competences and try to use these competences to influence politics, they start to attract actions for annulment.

The (presumed) right to adopt legally binding acts not only shapes empirical patterns of annulment litigation by influencing the list of potential defendants. It also influences the sector-specific prevalence of annulment litigation. Institutions' ability to adopt legally binding acts can vary from policy sector to policy sector as well as over time. For example, the Commission's competence to adopt legally binding measures varies across sectors (Franchino 2007). While the Commission may adopt legally binding decisions in the field of competition law, it does not enjoy this privilege to the same extent in the contexts of the EU's social policy or public health policy. Consequently, it cannot be surprising that we find a higher number of actions for annulment in the context of competition law than in the context of public health policy. Similarly, we see more actions for annulment in the context of state aid policy, as the Commission is able to enforce EU state aid law by adopting legally binding decision. In contrast, wherever the Commission fulfils its role as guardian of the treaties on the basis of adopting reasoned opinions in the context of infringement proceedings, we do not observe many actions for annulment. After all, reasoned opinions do not fall under the category of reviewable acts. Overall, this creates an exciting tension; while actions for annulment are particularly frequent in areas where EU institutions have far-reaching competences, they can be particularly influential in areas in which EU institutions are just starting to fight for these competences. After all, an aggressive push for more binding influence by an EU institution is likely to attract an action for annulment and will give the Court a chance to weigh in on whether this institutional power grab is compatible or incompatible with EU law. 


\section{An Evolving List of Applicants}

The unique feature of actions for annulment is that they allow actors to directly activate the Court. Yet EU law does not grant this right to all types of actors to the same extent. Different types of actors enjoy different privileges to directly challenge EU institutions at the CJEU. In fact, EU law distinguishes between so-called privileged applicants, semiprivileged applicants, and non-privileged applicants, where privileged applicants are the major institutional actors, the group of semi-privileged applicants consists of the more peripheral EU institutional actors, and the group of non-privileged applicants basically comprises regional governments, interest groups, companies, and individual citizens. ${ }^{3}$

Privileged applicants, listed in Article 263(2), do not have to fulfil any specific conditions for initiating annulment actions. When evaluating the admissibility of a case, the Court does not evaluate the standing rights of these applicants. Individual member states, the Council, the Commission, and since 1992, the EP make up the group of such privileged applicants. With respect to individual member states, the right to initiate annulment proceedings is limited to its governmental authorities and 'cannot be extended to regional governments or selfgoverning communities, regardless the extent of their powers' (joined cases T-32/98 and T-41/98, as well as joined cases T-132/96 and $\mathrm{T}-143 / 96)$. The Court thus treats regional authorities as non-privileged applicants (see below).

Semi-privileged applicants can be admitted to initiate an action for annulment when they are able to demonstrate that they do so "for the purpose of protecting their prerogatives'-as stipulated in Article 263(3). In contrast, privileged applicants are admitted even when cases do not involve their individual prerogatives. Today, the Court of Auditors, the ECB, and the Committee of the Regions make up this category of semi-privileged applicants. Before 1992, the EP was a part of this group as well. The inclusion of a semi-privileged group of applicants has been the result of an evolving EU polity and an evolving jurisprudence of the Court. Before the Treaty of Maastricht, the treaties only spoke of privileged and non-privileged applicants; with the EP not being part of the privileged applicants. Yet over time, the Parliament not only passively gained more power but also tried to actively increase its influence. Since these developments went hand in hand, the Parliament was 
able to make more and more convincing cases that the Council and the Commission were trying to interfere with its (newly gained) prerogatives. In Chernobyl (C-70/88), the EP attacked the legality of a Council regulation that established permitted levels of radioactive contamination of food because this regulation had been adopted on the basis of an inappropriate legislative procedure. It should have been adopted under a procedure that would involve the EP more substantially. In this particular case, the Court rejected the Council's objection that the EP was not an eligible applicant in this regard and established for the first time that it would generally consider the Parliament able to bring such cases wherever its own prerogatives were at stake. There are many cases in which EU institutions accuse each other of adopting legal acts on a wrong treaty base and to strategically pick an inappropriate legal procedure just to maximize their institutional influence (McCown 2003; Jupille 2004). The Courts interpretation of the Chernobyl case laid the ground for this new category of semi-privileged applicants. Subsequently, the Maastricht Treaty formalized this category and explicitly extended this right to the ECB. The Treaty of Amsterdam and the Treaty of Lisbon followed by further extending this list to include the Court of Auditors and the Committee of the Regions.

Finally, Article 263(4) TFEU extends the right to initiate annulment proceedings to 'any natural or legal person'. This group of applicants is commonly referred to as non-privileged applicants or private applicants, a label that indicates the stricter conditions of admissibility that these actors face. Although the term 'private applicants' is often used as a synonym of non-privileged applicant, this category can also entail public authorities. In fact, regional governments, such as state governments or also municipalities, are an important part of this group of non-privileged actors.

The classification of regional governments, such as the German Länder, as non-privileged actors is quite consequential in this regard, as this keeps them from sending to the CJEU their own lawyers, who are not officially recognized at the CJEU bar. Unlike member states' governments, whose internal lawyers can plead before the CJEU, regions have to delegate their legal representation. This represents an additional hurdle when trying to initiate an action for annulment.

Overall, legal scholars have repeatedly described the conditions that non-privileged actors have to fulfil to be admitted to court with annulment actions to be 'notoriously strict' (Arnull 2001, 7) or even as an 
'almost insurmountable barrier' (Barav 1974). And yet today, this group of applicants brings the majority of annulment actions to the Court's attention despite facing a relatively strict admissibility test. Nevertheless, the Court has been a bit more self-restrained when developing the standing rights of this applicant group then it has with respect to the EP and other EU institutions. ${ }^{4}$ To a large extent, this conservative position is justified with reference to the role of the Article 267 TFEU preliminary reference proceedings. The Court has held that both procedures have to be seen in combination to understand the EU's system of judicial review. After all, in most cases, it should be sufficient for citizens to turn to national courts to enforce their rights and-where necessary-to press the national court to demand a preliminary ruling from the CJEU. In the context of such preliminary rulings, the CJEU can be asked to assess the validity of acts adopted by EU institutions. Only where this preliminary reference procedure is unavailable, should non-privileged actors have the chance to turn to the CJEU directly.

Consequently, actions for annulment are not available to non-privileged actors in case the contested EU legal act is not of direct concern to them. To the Court, this direct concern requirement means that the 'measure must directly affect the legal situation of the person concerned and its implementation must be purely automatic and result from Community rules alone without the application of other intermediate rules' (T-69/99). Therefore, non-privileged actors can have a hard time demonstrating that they are directly concerned by a European directive or by a decision addressed to a member state, for example. This does not mean, however, that non-privileged actors have never been able to successfully challenge such acts (e.g. C-386/96P or C-291/89).

In addition to having to demonstrate their direct concern, nonprivileged applicants have to demonstrate that they are individually concerned by EU legal acts as well. What this means has essentially been developed in the Court's Plaumann ruling (C-25/62), where the Court held that 'persons other than those to whom a decision is addressed may only claim to be individually concerned if that decision affects them by reason of certain attributes which are peculiar to them or by reason of circumstances in which they are differentiated from all other persons and by virtue of these factors distinguishes them individually just as in the case of the person addressed'. One of the ironies of this interpretation is that particularly in those cases where the adverse effects of EU legal acts are rather widespread and affect many non-privileged actors at the 
same time, each of them will have a very hard time fulfilling the individual concern criterion and challenging the respective legal act before the Court (Moser and Sawyer 2008, 84f.).

Generally speaking, the relatively high hurdles that non-privileged actors must overcome to establish individual concern when trying to challenge regulations and directives initially formulated in Plaumann is upheld to this day. This does not mean, however, that non-privileged actors have never tried to challenge regulations and directives. They have done so and continue to do so despite being aware of the relatively low chance of having cases admitted to the Court. While the Court in Codorniu v. Council (C-309/89) had been interpreted by some legal scholars as a breakthrough for private actors' standing rights, subsequent case law quickly dissolved these kinds of hopes for easier access to the Court (Arnull 2001). Nevertheless, this case, in which a Spanish producer of Crémant challenged a Commission regulation that would only allow producers from France and Luxembourg to label their high-quality sparkling wine Crémant, helped to establish that non-privileged actors could in fact challenge true regulation and true directives (Arnull 2001, 80). However, later attempts to revise the so-called Plaumann test to assess the individual concern of directives and regulations have been rejected by the Court. In UPA (C-50/00), Advocate General Francis Jacobs had criticized the restrictive Plaumann test as inappropriate and proposed a less restrictive test for individual concern. The Court did not follow his opinion in this regard, however (Moser and Sawyer 2008, 85). Interestingly, when the French fishing company Jégo Quére attacked a Commission directive that specified new minimum mesh sizes, the General Court handling the case at first instance tried to introduce a less restrictive reformulation of the Plaumann formula (T-177/01). When the Commission appealed against the Court's at the Court of Justice, however, the Court of Justice overruled this modification and reconfirmed its determination to stick to the Plaumann formula (Moser and Sawyer 2008, 90).

One important change of primary law that came with the Lisbon Treaty was an addition to Article 263(4) TFEU. Here, the member states explicitly stated that regulatory acts that do not entail implementation measures would be reviewable with the annulment procedure. This would get rid of the individual concern criterion, which has continued to be a substantial hurdle for private litigants to effectively have EU legal acts reviewed before the Court, at least as long as regulatory acts did not 
entail further implementing measures. Yet since the treaty abstained from defining what a regulatory act and implementing measures entailed specifically, it was - and still is - up to the Court to bring forward more specific definitions (Craig 2010). This is what the Court continues to do. In Inwit (C-583/11 P), for example, the Court established that it considered regulatory acts to be acts of general applicability (such as directives and regulations) that have not been adopted under the ordinary or special legislative procedure (Peers and Costa 2012). For acts adopted under these legislative procedures, non-privileged actors would thus still have to establish direct concern and individual concern to have the Court assess whether an annulment action is indeed founded. Moreover, in subsequent judgements, the Court upheld rather restrictive interpretations of what implementing measures entailed, sometimes even rejecting opinions by the respective advocate general (e.g. TéL Sugars [C-456/13 P]).

\section{Conclusion}

With this necessarily brief and selective overview over the legal background of actions for annulment, we have tried to highlight, among other things, that actions for annulment are not the only instrument through which the Court can be brought to review the legality of supranational actions. Yet quite importantly, they are the only instruments with which member states, other EU institutions, and even citizens, companies, or interest groups can directly invoke the Court. Moreover, the rules and interpretations guiding the conditions under which these different kinds of actors can successfully initiate actions for annulment have evolved considerably since the early days of the European project. Generally speaking, this road to Luxembourg has become broader and more accessible, allowing for the review of more legal acts by more types of actors. Typically, this evolution is seen to be driven by the judges at Luxembourg, who have helped to develop the annulment procedure through case law that has repeatedly led to the revision of primary law. Since the openness and shape of a legal system definitely influences the impact of this legal system on the resolution of political conflict, the political balance of power, and the general dynamic of policy processes (Hilson 2002; Andersen 2006; Wilson and Rodriguez Cordero 2006; Vanhala 2012), actions for annulment are likely to become even more important as a tool with which one can still leave a mark in an increasingly heterogeneous and fragmented European Union. 
The legal evolution of actions for annulment has been influenced particularly strongly by annulment actions launched in areas where their admissibility was seen as highly questionable. It was those cases that required the Court to set the future course of this legal instrument. In this regard, the Court's interpretations have at times answered objective needs, for example, when the EP's legal acts were included in the list of supranational acts eligible for annulments (e.g. C-294/83, T-16/04, $\mathrm{T}-308 / 07)$. Such formal review of parliamentary acts was not needed as long as the powers of the EP remained merely symbolic. In this sense, the extension of annulments to comprise the EPs' acts was the logical consequence of the shifting balance of power in the supranational institutional order. A similar logic applied in those cases where the EP brought annulments against other institutions' actions to the Court (e.g. C-70/88, C-65/90, C-295/90). In the original treaty provision, the Parliament did not have the formal right to do so; the Court conferred this right, however, to the EP via its case law, and later, this change of legal doctrine found its way to into the treaty (McCown 2003).

While many legal scholars continue to question whether the rules that guide the admission of actions brought by non-privileged actors provide effective judicial protection (Eliantonio and Kas 2010; Kornezov 2014), the gradual extension of the scope of application of annulment actions, as well as the rising empirical importance of annulment actions over time, reflect the ever-greater powers delegated to the EU and its increasing internal sophistication. In itself, the evolution of annulments indicates the increasing maturity of the EU as a political system and supports our argument about the growing conflict potential in the EU multilevel system.

Nevertheless, the evolving rules on reviewable acts under, and eligible applicants for, actions for annulment influence the empirical patterns of annulment litigation. Semi-privileged actors, such as the ECB or the Court of Auditors, can only challenge those acts in order to defend their own prerogatives. Consequently, we see actions for annulments launched by these institutions where they do have prerogatives or where they claim to have prerogatives. Because of the relatively strict rules on admitting cases by companies, for example, many annulment actions initiated by these actors emerge in the context of competition and state aid law where these actors can often make a relatively strong case for being directly and individually concerned. And yet the sheer mass of actions for annulment in any one area does not necessarily determine the impact of actions for annulment in that area. On the contrary, areas with relatively 
few actions for annulment are areas where EU institutions only start to claim the right to act in legally binding ways. In those cases, the Court's assessment of that right is arguably quite influential for the future course of European integration.

Finally, in strictly legal terms, actions for annulment serve a rather clear legal purpose. They represent a legal attack on an EU institution that is claimed to have overstepped its mandate or at least has allegedly neglected procedural requirements. Consequently, the respective EU institution appears in Court as the defendant. From a legal standpoint, it is thus clear who the defendant is in this constellation. Interestingly, this is much less clear from a political perspective. After all, for member states, regional governments, and other subnational actors, the initiation of an annulment action can often be a measure of last resort to fend off legally binding interference by EU institutions that are perceived as illegitimate, inappropriate, politically inopportune, very costly, or all of the above. Politically, they try to defend their political realm against supranational interferences. Making use of the EU's legal system can be an important part of such a defence. Therefore, in the next chapter, we turn to these political motivations to initiate actions for annulment.

\section{Cases Cited}

See Table 3.1.

Table 3.1 Cases cited in this chapter

\begin{tabular}{ll}
\hline C-25/62 & Judgement of 15 July 1963, Plaumann v. Commission, C-25/62, \\
& EU:C:1963:17 \\
C-22/70 & Judgement of 31 March 1971, Commission v. Council, C-22/70, \\
& EU:C:1971:32 \\
C-138/79 & Judgement of 29 October 1980, Roquette v. Council, C-138/79, \\
& EU:C:1980:249 \\
C-295/90 & Judgement of 7 July 1992, Parliament v. Council, C-295/90, \\
& EU:C:1992:294 \\
C-60/81 & Judgement of 11 November 1981, IBM v. Commission, C-60/81, \\
& EU:C:1981:264 \\
C-294/83 & Judgement of 23 April 1986, Les Verts v. Parliament, C-294/83, \\
& EU:C:166 \\
C-70/88 & Judgement of 22 May 1990, Parliament v. Council, C-70/88, \\
& EU:C:1990:217
\end{tabular}


Table 3.1 (continued)

\begin{tabular}{|c|c|}
\hline $\mathrm{C}-70 / 88$ & $\begin{array}{l}\text { Judgement of } 22 \text { May 1990, Parliament v. Council, C-70/88, } \\
\text { EU:C:1990:217 }\end{array}$ \\
\hline C-291/89 & $\begin{array}{l}\text { Judgement of } 7 \text { May 1991, Interhotel v. Commission, C-291/89, } \\
\text { EU:C:1991:189 }\end{array}$ \\
\hline C-309/89 & $\begin{array}{l}\text { Judgement of } 18 \text { May 1994, Codorniu v. Council, C-309/89, } \\
\text { EU:C:1994:197 }\end{array}$ \\
\hline C- $65 / 90$ & $\begin{array}{l}\text { Judgement of } 16 \text { July 1992, Parliament v. Council, C-65/90, } \\
\text { EC:EU:C:1992:325 }\end{array}$ \\
\hline C-57/95 & $\begin{array}{l}\text { Judgement of } 20 \text { March 1997, France v. Commission, C-57/95, } \\
\text { EU:C:1997:164 }\end{array}$ \\
\hline C-386/96P & $\begin{array}{l}\text { Judgement of } 5 \text { May 1998, Dreyfus v. Commission, C-386/96P, } \\
\text { EU:C:1998:193 }\end{array}$ \\
\hline C-50/00 & Judgement of 25 July 2002, UPA v. Council, C-50/00, EU:C: 2002:462 \\
\hline C-583/11 P & $\begin{array}{l}\text { Judgement of } 3 \text { October 2013, Inuit v. Parliament and Council, } \\
\text { C-583/11P, EU:C:2013:625 }\end{array}$ \\
\hline C- $456 / 13 \mathrm{P}$ & $\begin{array}{l}\text { Judgement of } 28 \text { April 2015, TéL Sugars v. Commission, C-456/13P, } \\
\text { EU:C:2015:284 }\end{array}$ \\
\hline $\mathrm{T}-32 / 98$ & Judgement of 10 February 2000, Nederlandse Antillen v. Commission, \\
\hline $\mathrm{T}-41 / 98$ & Joined Cases T-32/98 and T-41/98, EU:T:2000:36 \\
\hline T-132/96; & Judgement of 15 December 1999, Saxony and VW v. Commission, Joined \\
\hline $\mathrm{T}-143 / 96$ & Cases 132/96 and T-143/96, EU:T:1999:326 \\
\hline T-69/99 & $\begin{array}{l}\text { Judgement of } 13 \text { December 2000, DSTV v. Commission, T-69/99, } \\
\text { EU:T:2000:302 }\end{array}$ \\
\hline
\end{tabular}

\section{Notes}

1. Article 263 TFEU reads as follows: 'The Court of Justice of the European Union shall review the legality of legislative acts, of acts of the Council, of the Commission and of the European Central Bank, other than recommendations and opinions, and of acts of the European Parliament and of the European Council intended to produce legal effects vis-à-vis third parties. It shall also review the legality of acts of bodies, offices or agencies of the Union intended to produce legal effects vis-à-vis third parties. It shall for this purpose have jurisdiction in actions brought by a Member State, the European Parliament, the Council or the Commission on grounds of lack of competence, infringement of an essential procedural requirement, infringement of the Treaties or of any rule of law relating to their application, or misuse of powers. The Court shall have jurisdiction under the same conditions in actions brought by the Court of Auditors, by the European Central Bank and by the Committee of the Regions for the purpose of protecting their prerogatives. Any natural or legal person may, under the conditions laid down in the first and second paragraphs, institute proceedings 
against an act addressed to that person or which is of direct and individual concern to them, and against a regulatory act which is of direct concern to them and does not entail implementing measures. Acts setting up bodies, offices and agencies of the Union may lay down specific conditions and arrangements concerning actions brought by natural or legal persons against acts of these bodies, offices or agencies intended to produce legal effects in relation to them. The proceedings provided for in this Article shall be instituted within two months of the publication of the measure, or of its notification to the plaintiff, or, in the absence thereof, of the day on which it came to the knowledge of the latter, as the case may be'.

2. We have already discussed the ERTA judgements implied powers doctrine in Chapter 1 and will also touch on it in Chapter 5.

3. This terminology is not the terminology of the treaties. Yet the terms 'privileged applicant', 'semi-privileged applicant', and 'non-privileged applicant' are widely used in legal scholarship.

4. See above with the ERTA and Chernobyl cases, for example.

\section{REFERENCES}

Alter, K. J. (1998). Who are the "masters of the treaty"? European governments and the European Court of Justice. International Organization, 52(1), $121-147$.

Andersen, E. A. (2006). Out of the closets and into the courts: Legal opportunity structure and gay rights litigation. Ann Arbor: University of Michigan Press.

Arnull, A. (2000). The action for annulment: A case of double standards? In D. O'Keefe (Ed.), Judicial review in European Union law (pp. 177-190). The Hague: Kluwer Law International.

Arnull, A. (2001). Private applicants and the action for annulment since CODORNIU. Common Market Law Review, 38, 7-52.

Arnull, A. (2006). The European Union and its Court of Justice. Oxford, UK: Oxford University Press.

Arnull, A. (2011). The principle of effective judicial protection in EU law: An unruly horse. European Law Review, 1, 51-70.

Barav, A. (1974). Direct and individual concern: An almost insurmountable barrier to the admissibility of individual appeal to the EEC court. Common Market Law Review, 11(2), 191-198.

Bellamy, C. (2010). An EU competition court: The continuing debate. In I. Kokkoris \& I. Lianos (Eds.), The reform of EC competition law: New challenges (pp. 33-52). Alphen aan den Rijn, The Netherlands: Kluwer Law International.

Börzel, T. A. (2003). Guarding the treaty: The compliance strategies of the European Commission. In T. A. Börzel \& R. A. Cichowski (Eds.), The state of 
the European Union (6th ed., pp. 197-220). Oxford, UK: Oxford University Press.

Conant, L. J. (2006). Individuals, courts, and the development of European social rights. Comparative Political Studies, 39(1), 76-100.

Craig, P. (2010). The Lisbon Treaty: Law, politics, and treaty reform. Oxford, UK: Oxford University Press.

Craig, P., \& de Búrca, G. (2011). EU law: Text, cases, and materials. Oxford, UK: Oxford University Press.

Eliantonio, M., \& Kas, B. (2010). Private parties and the annulment procedure: Can the gap in the European system of judicial protection be closed? Journal of Politics and Law, 3(2), 2-121.

Fairhurst, J. (2010). Law of the European Union. London: Pearson Education.

Falkner, G. (2018). A causal loop? The Commissions new enforcement approach in the context of non-compliance with EU law even after CJEU judgments. Journal of European Integration, 40, 769-784.

Franchino, F. (2007). The powers of the union: Delegation in the EU. Cambridge, UK: Cambridge University Press.

Hartlapp, M. (2005). Die Kontrolle der nationalen Rechtsdurchsetzung durch die Europäische Kommission. Frankfurt: Campus Verlag.

Hartley, T. C. (2007). The foundations of European Community law: An introduction to the constitutional and administrative law of the European Community. Oxford, UK: Oxford University Press.

Hilson, C. (2002). New social movements: The role of legal opportunity. Journal of European Public Policy, 9(2), 238-255.

Horspool, M., \& Humphreys, M. (2012). European Union law. Oxford, UK: Oxford University Press.

Jupille, J. (2004). Procedural politics: Issues, influence, and institutional choice in the European Union. Cambridge, UK: Cambridge University Press.

Kornezov, A. (2014). Locus standi of private parties in actions for annulment: Has the gap been closed? The Cambridge Law Journal, 73, 25-28.

McCown, M. (2003). The European Parliament before the bench: ECJ precedent and EP litigation strategies. Journal of European Public Policy, 1O(6), 974-995.

Moser, P., \& Sawyer, K. (Eds.). (2008). Making community law: The legacy of Advocate General Jacobs at the European Court of Justice. Cheltenham, UK: Edward Elgar.

Peers, S., \& Costa, M. (2012). Court of Justice of the European Union (General Chamber), Judicial review of EU Acts after the Treaty of Lisbon; Order of 6 September 2011, Case T-18/10 Innit Tapiriit Kanatami and Others vs. Commission \& Judgment of 25 October 2011, Case T-262/10 Microban vs. Commission. European Constitutional Law Review, 8(1), 82-104. 
Tallberg, J. (2002). Paths to compliance: Enforcement, management, and the European Union. International Organization, 56, 609-643.

Türk, A. (2009). Judicial review in EU law. Cheltenham, UK: Edward Elgar.

Vanhala, L. (2012). Legal opportunity structures and the paradox of legal mobilization by the environmental movement in the UK. Law and Society Review, $46(3), 523-556$.

Wilson, B., \& Rodriguez Cordero, J. C. (2006). Legal opportunity structures and social movements: The effects of institutional change on Costa Rican politics. Comparative Political Studies, 39(3), 325-351.

Open Access This chapter is licensed under the terms of the Creative Commons Attribution 4.0 International License (http://creativecommons.org/licenses/ by $/ 4.0 /$ ), which permits use, sharing, adaptation, distribution and reproduction in any medium or format, as long as you give appropriate credit to the original author(s) and the source, provide a link to the Creative Commons license and indicate if changes were made.

The images or other third party material in this chapter are included in the chapter's Creative Commons license, unless indicated otherwise in a credit line to the material. If material is not included in the chapter's Creative Commons license and your intended use is not permitted by statutory regulation or exceeds the permitted use, you will need to obtain permission directly from the copyright holder.

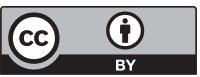

